\title{
THE DISPOSITION EFFECTS ON THE FINANCIAL CRISIS OF THE INDONESIAN CAPITAL MARKET
}

\author{
Rohmad Fuad Armansyah \\ Banking and Finance Diploma, STIE Perbanas Surabaya, Surabaya 60118, Indonesia \\ Email: fuad@perbanas.ac.id
}

\begin{abstract}
Disposition effects can be positive but can also have a negative impact on capital market activity. Positive if the behavior of selling or holding the assets is done after obtaining enough information on the investments, so that the market becomes dynamic, in the contrary, it will be negative if the behavior of selling / holding the assets by investors on the basis of not wanting to lose or because of the expectations in the future could lead to destruction or financial crisis. These behavior in some research causing the market unstable while other did not find disposition appear in their market. This research is to examine whether there is a behavior of the disposition effect before the crisis, during the crisis, and after the financial crisis of 2013 on the Indonesian capital market. The data of LQ45 group companies are used in this study with 810 observations as the data of disposition effect base on investor trading through brokerage firm. The results show that there is no disposition effect behavior in financial crisis especially as what happened in Indonesia in 2013.
\end{abstract}

Keywords: Disposition effect, financial crisis, behavioral economic, one-way ANOVA.

\section{Introduction}

The development of a country has always been interesting for investors. One thing that attracts them is the stock market. The Indonesian Stock Exchange is a dynamic stock market with the active trade and many of foreign and domestic investors who actively trade. Indonesian Stock Exchange started in 1912 with a very old-fashioned system which then turned to the remote trading system then online system to make the capital market as a media of channeling funds and investment facilities for the parties in need. Indonesian Stock Exchange also experienced a very important phase of information development. Information becomes very important for investors in making investment decisions.

Information is needed by investors in the investment decision. Investors need more information related to the opportunities to invest so as to create informed investors and uninformed investors. The condition of investors who feel less informed is weak in investment decisions, so will try to find and will assume that other investors have more information. This lack of information will also encourage investors to have more expectations of the investments that have been made so tends to quickly sell the assets that are owned while retaining assets whose value decreasing so the losses possibly occurred and this action could make the stock prices fall. According to Gomes (2005), investors who avoid losses will sell their shareholdings to protect themselves against losses. This behavior is called a disposition effect and is a deviant behavior in investments. Such behavior makes the market unstable and insecure in investing.

The disposition effect is the development of the prospect theory by Kahneman and Tversky (1979). Prospect theory shows that most investors will behave risk averse if faced with the opportunity to get a profit on their investment, but if faced with opportunities that raises the possibility of loss (loss) in investment, investors will tend to take risks. This is because investors do not want to lose.

Disposition effects can be positive but also can have a negative impact on capital market activity. Positive if the behavior of selling/ holding assets activity after obtaining enough information, so that the market becomes dynamically developing, in the contrary, it will be negative if the behavior of selling/ holding assets conducted by investors on the basis of not wanting to lose or because of the expectations in the future will lead to the destruction or financial crisis as happen in the Indonesian capital market during the Asian financial crisis of 1997 to 1998 (Bonser-Neal, Jones, Linnan, \& Neal, 2002; Bowe \& Domuta, 2004; Agarwal, Chiu, Liu, \& Rhee, 2010). Research on the behavior of disposition effects, especially in the period of the financial crisis is still interesting to study. Based on the description above, this study examines whether there is a difference in disposition effect behavior before, during and after the 2013 financial crisis in the Indonesian capital market and is expected to provide insight related to economic behavioral so that investors get insight into behavior that may exist in the Indonesian capital market. 
Behavior finance describes how humans interpret and act on information to make financial decisions (Lintner, 1998). Behavior finance is not only about human actions, but also an understanding of investors' reasoning patterns including the emotional factors involved to the extent of their influence in the decision-making process (Ricciardi \& Simon, 2000).

Ritter (2003), argues that behavior finance is a behavior based on psychology that affects the decision process consisting of two parts, cognitive and limit to arbitrage. Bodie, Kane, and Marcus (2008), explaining that investors are not always able to process data correctly so that it will create the false probability distribution in the prediction of investment return. Then, if the distribution is in the real situation, investors tend to make decisions that are not optimal. These two things confirm that investors think is irrational in decision making.

Research by Goetzmann and Massa (2008) proved that at the time of the disposition of investors doing transaction, then the volatility, stock returns, and trading volume of stocks fell. These results add to evidence of a behavioral bias in the stock market further disposition effect can be able to affect the price of individual stocks at the stock market level.

Booth, Kallunki, Sahlstro, and Tyynela, (2011) by looking at the response between the types of foreign and domestic investors regarding stock information, by processing the data of investor stock ownership in Finland from the Central Finnish Securities Depository, shows the result that after the announcement by the issuer that is negative it will be responded by foreign investor with selling shares of the issuer who report the negative information.

Riaz, Hunjra and Azam (2012) examined the effect of psychological factors on investor decisions. The results showed that the perception of risk is very influential in making investment decisions. Investor behavior depends on how available information is presented to them and how much they take risks in making decisions, so this plays an important role in determining the investment style of the investor.

Research by Eichengreen, Rose, and Wyplosz (1994) and Kaminsky, Lizondo, and Reinhart (1998), concluded that prior to the financial crisis is usually preceded by sharply increasing banking activity and rapidly declining after the crisis. The increase in banking activity was marked by an increase in capital flows, an increase in M2 multiplier by 20 percent higher than the quiet period, the growth in domestic credit to GDP ratio that rose sharply and peaked in times of crisis.

Other studies that also focus on modeling the financial crisis using the MARS (Multivariate Analysis Regression Splines) method is by Armansyah and Effendi (2017) on the Indonesian capital market. Ex- change Market Pressure Index-EMPI as an approach to measure and detect the crisis approach using 11 macroeconomic factors (export growth, import growth, foreign exchange reserves, inflation, rupiah exchange rate against US dollar, money supply, BI interest rate, composite stock price index, LIBOR, SIBOR, US prime Rate) shows that in the period of 2005 to 2014 there were two crisis times in Indonesia, that are in 2008 and 2013. The model shows that the US Prime Rate as a macro factor influences the occurrence of the financial crisis. Although the US Prime Rate did not change during this period, it could make changes in economic conditions, especially in the Indonesian capital market with the parameters used in the study.

\section{Disposition Effect}

The disposition effect is the hasty behavior of investors in realizing the investment profits but withholding the long-term losses that can occur, or it can be said that investors are avoiding risks when facing profit-taking and risk-taking conditions when losses occur. Shefrin and Statman (1985) first discovered a disposition effect as a continuation of Kahneman and Tversky's (1979) research. They then developed the theory of capital gains and losses in which investors tend to sell too early and hold losses for too long. These results are also in line with Odean (1998), Grinblatt and Han (2005) findings showing evidence of behavioral disposition effect where the expected return of a stock is positively proportional to the ratio of stock market prices and the acquisition price either in the future or in the year then. Indrayono (2011) who conducted a disposition effect study as a moderating variable in the 2008 financial crisis period is also in line with the results of the study, further proving that as moderation, the disposition effect weakens the positive relationship of fundamental stock values (EPS and book value per share) with stock prices. While Dhar and Zhu (2006) prove that a lower level of disposition effect is found in prosperous individuals and work professionally.

Disposition effect is calculated using a formula developed by Odean (1998), which is also used in Dhar and $\mathrm{Zu}$ (2006) and also Goetzmann and Massa (2008), as follows:

Which:

$$
D E=P G R-P L R
$$

$$
\begin{gathered}
P G R=\text { Proportion of Gains Realized } \\
=\frac{\text { Realized Gains }}{\text { Realized Gains + Paper Gains }} \\
P L R=\text { Prportion of Losses Realized } \\
=\frac{\text { Realized Losses }}{\text { Realized Losses + Paper Losses }}
\end{gathered}
$$




\section{Exchange Market Pressure Index (EMPI)}

In general, the crisis (in this case the financial crisis) is defined as the occurrence of a decline in the exchange rate of a country's currency against a foreign currency (devaluation) caused by pressure on the exchange market. The exchange market pressure index using a formula developed by Heun and Schlink (2004) as follows.

$$
\text { EMPI }=\left(\frac{1}{\sigma_{\mathrm{p}}}\right)\left(\Delta_{\mathrm{p}}\right)+\left(\frac{1}{\sigma_{\mathrm{q}}}\right)\left(\Delta_{\mathrm{q}}\right)-\left(\frac{1}{\sigma_{\mathrm{r}}}\right)\left(\Delta_{\mathrm{r}}\right)
$$

Remarks:

EMPI : exchange market pressure index

$\sigma_{p} \quad$ : standard deviation from changes in the rupiah against the US Dollar

$\sigma_{q} \quad$ : standard deviation from interest rate changes

$\sigma_{r} \quad$ : standard deviation from changes in foreign exchange reserves

$\Delta_{p} \quad: \quad$ changes in the rupiah against the US Dollar

$\Delta_{q} \quad$ : interest rate changes

$\Delta_{r} \quad$ : changes in foreign exchange reserves

Limiting the value of the market pressure index to the exchange rate by setting up the upper limit the threshold of the index may indicate a financial crisis in a country. The economy is said to be crisis if the $E M P I$ in that period exceeds the average of EMPI index plus the standard deviation multiply by $m$. The $m$ value is a threshold following the model used by the World Bank that is 1.5 times (as $m$ ) of the standard deviation. The value of $m$ used in several studies of crisis has different values. Note that the smaller use of $m$ values, mean more careful in seeing the potential of the crisis and possible detected more periods were indicated crisis. We can say that the financial crisis occurred if $E M P I_{t}>\mu_{E M P I}+m \sigma_{E M P I} ; \mu_{E M P I}$ is the average of the EMPI index and $m \sigma_{E M P I}$ denotes as the threshold multiply by standard deviation of its EMPI index.

\section{Research Method}

This research uses data of the trading of companies included in LQ45 processed using formula developed by Odean (1998) as approach of disposition effect and exchange market pressure index (EMPI) as determinant of crisis period of January 2012 until December 2014 at Indonesia Stock Exchange. The data is processed using SPSS 23 software through several stages. The number of observations is 810 observations with a period of 18 months with details of sixmonth period (before, during, after crisis). The variable used is the disposition effect developed by Odean (1998). The disposition effect will be tested on condition before crisis, when the crisis, and after crisis. For the Exchange Market Pressure Index is using a formula developed by Heun and Schlink (2004).

\section{Result and Discussion}

The Exchange Market Pressure Index measures the decline in the exchange rate of a country's currency against a foreign currency (devaluation) as a result of pressure on the exchange rate market. Foreign currency refers to the common currency used in foreign financial transactions. Especially in the country of Indonesia, the currency commonly used as foreign exchange transactions is the US Dollar.

The Exchange Market Pressure Index uses a threshold in classifying the occurrence of a crisis or not. Thresholds for measuring crises have varying references where smaller threshold levels indicate caution and more stringency in view of potential crises and may detect more periods indicated the

Table 1

The Exchange Market Pressure Index

\begin{tabular}{lccr}
\hline Period & $\mathbf{2 0 1 2}$ & $\mathbf{2 0 1 3}$ & $\mathbf{2 0 1 4}$ \\
\hline January & -0.861 NORMAL & 1.221 NORMAL & -3.108 NORMAL \\
February & -0.899 NORMAL & 1.002 NORMAL & 0.933 NORMAL \\
March & 0.972 NORMAL & 0.335 NORMAL & -1.434 NORMAL \\
April & -1.935 NORMAL & -0.850 NORMAL & -0.396 NORMAL \\
May & 2.611 CRISIS & 1.168 NORMAL & -0.157 NORMAL \\
June & 1.579 NORMAL & 3.710 CRISIS & 0.398 NORMAL \\
July & 0.085 NORMAL & 4.438 CRISIS & -1.893 NORMAL \\
August & -0.509 NORMAL & 4.547 CRISIS & 0.106 NORMAL \\
September & -0.346 NORMAL & 0.659 NORMAL & 1.558 NORMAL \\
October & 0.074 NORMAL & -0.858 NORMAL & -0.596 NORMAL \\
November & -0.372 NORMAL & 3.084 CRISIS & 1.556 NORMAL \\
December & 0.027 NORMAL & -0.227 NORMAL & 0.316 NORMAL \\
World Bank Limit Threshold & 2.541 & & \\
Standard deviation & 1.694 & &
\end{tabular}


crisis, and vice versa. A threshold widely referred to as an economic benchmark is a model used by the World Bank that is 1.5 times the standard deviation of EMPI.

The Indonesian financial crisis detected in the timeframe of January 2012 to December 2014 (Table 1) using the World Bank's standard threshold of 2.541 which is 1.5 times the standard deviation of EMPI, detected once in 2012 and 4 times in 2013 on in May 2012 with an EMPI of 2.611 slightly above the threshold of provisions, then June, July, August, and November 2013 with EMPI value reaching 3.710 in June, increasing to 4.438 in July and increasing again to 4.546 in August 2013. In November the financial crisis again occurred with the value of EMPI lower than in June, July, and August amounted to 3.084. The results of the detection of the financial crisis that occurred in 2013 to limit the determination of the period before the crisis, during the crisis, and the period after the crisis.

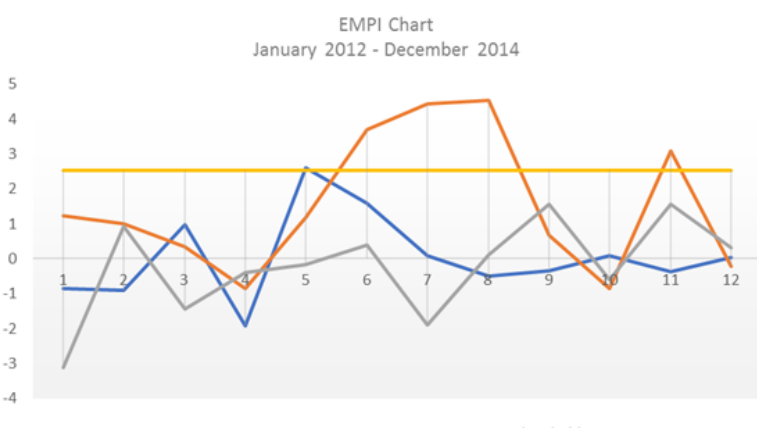

Figure 1. Chart of Indonesian financial crisis with empi approach period January 2012 to December 2014

The DE data used are trading data of shares traded by investor on the LQ45 group from the brokerage firm regarding the trade transactions of the investors incorporated in the company. Based on Table 2 can be seen in the period before the crisis, the minimum disposition effect value reached -2.8465 and this value is close to the minimum value during the crisis period of -2.8506 , but the maximum value at the time of crisis is higher than before the crisis, i.e. at 3.8051 during the crisis and 2.7572 during the crisis.

\section{Normality Test}

This test is performed to determine the samples used have been normal distributed or not. If the data is not normally distributed, then use non-parametric statistical methods. The results of normality test data can be seen in Table 3 which shows that the data has been distributed normally with a significance level of 0.055 or greater than 0.05 with a statistical value of 0.032 on the test of Normality using One-Sample Kolmogorov-Smirnov Test, because the significance is greater than 0.05 then we may conclude that the data has been normally distributed.

Table 3

Normality Test

\begin{tabular}{cccc}
\hline Variable & Number of Data & Statistics & Sig. \\
\hline$X_{1}$ & 810 & 0.032 & 0.055 \\
\hline
\end{tabular}

\section{Homogeneity Test}

Based on Table 4 can be seen significance of 0.921 greater than 0.05 so it can be concluded that the three groups of data based on the period of occurrence of the crisis has the same variant. Levene Statistic value show 0.082 we can conclude that the greater the homogeneity.

Table 4

Homogeneity Test

\begin{tabular}{ccccc}
\hline Variable & Levene Statistic & $\boldsymbol{d} \boldsymbol{f}_{\boldsymbol{I}}$ & $\boldsymbol{d} \boldsymbol{f}_{2}$ & Sig. \\
\hline$X_{I}$ & 0.082 & 2 & 807 & 0.921 \\
\hline
\end{tabular}

In Table 5 the results of one-way ANOVA show the value of $p$ value 0.883 where this is close to 1 (one) and greater than the significance level of 0.05 $(0.883>0.05)$, so it can be concluded that there is no behavior of disposition effect before the crisis, during the crisis, or after the financial crisis of 2013 in the Indonesian capital market. The result is also supported by the result of $F_{\text {count }}$ which has a value of 0.124 which is smaller than $F_{\text {table }}$ of 3.00 , so there is no behavior of disposition effect in the data group used.

Table 2

Descriptive of Disposition Effect Data

\begin{tabular}{lcccccc}
\hline \multicolumn{1}{c}{ Period } & The data & Mean & Minimum & Maximum & Standard Deviation & $\begin{array}{c}\text { Standard } \\
\text { Error }\end{array}$ \\
\hline Before Crisis & 270 & 0.04888 & -2.8465 & 2.7572 & 1.0217 & 0.0622 \\
When Crisis & 270 & 0.05179 & -2.8506 & 3.8051 & 1.0526 & 0.0640 \\
After Crisis & 270 & 0.01220 & -3.4786 & 2.4940 & 1.0098 & 0.0615 \\
Total Data & 810 & 0.03763 & -3.4786 & 3.8051 & 1.0270 & 0.0361 \\
\hline
\end{tabular}


Table 5

One-Way ANOVA Test

\begin{tabular}{lrrrrr}
\hline & $\begin{array}{r}\text { Sum of } \\
\text { Square }\end{array}$ & $\boldsymbol{d} f$ & $\begin{array}{r}\text { Mean } \\
\text { Square }\end{array}$ & $\boldsymbol{F}$ & Sig. \\
\hline Between Groups & 0.263 & 2 & 0.131 & 0.124 & 0.883 \\
Within Groups & 853.095 & 807 & 1.057 & & \\
\hline
\end{tabular}

\section{Disposition Effect on Financial Crisis}

Behavior of disposition effect becomes a challenge for capital market investors, although this behavior can also occur on various aspects of the market or other trade. This behavior is basically always present in every trade transaction, it's just that the effect may be diverse. Significant effects can result in high market volatility, and vice versa. Capital market becomes one of the many trading places involving the perception and thinking of investors in decision making, so is very possible existence of disposition effect. Economic conditions are also closely related to investor perspectives in decision making. The economic growth will facilitate investors to make decision in all investment options, this different with the economic while in crisis conditions. Investors will be more selective in choosing an investment and create decision.

The disposition effect on the financial crisis that became the topic in this study has shown different results from previous research. The results of this study indicate that there is no difference or no behavior of disposition effect at the time of Indonesia's financial crisis in 2013 by using the data period January 2012 to December 2014, especially in the stock group LQ45. This result is different from previous research conducted by Grinblatt and Han (2005), Indrayono (2011), Dhar and Zhu (2006), Shefrin and Statman (1985) that found the disposition effect phenomenon. This finding is possible to be differ due to different capital market locations, the period used, and also the investors have learned from the experience of previous crisis conditions in 1998 and 2008, so that the financial crisis that occurred in 2013 is not so impact on the economy. The use of different approaches to financial crises also permits different research results from previous research by Indrayono (2011) using a crisis approach that has been officially announced by the media while in this research using the approach of Exchange Market Pressure Index (EMPI) as an approach to determine the period of financial crisis.

\section{Conclusion and Implication}

This study examines the behavior of the disposition effect in the condition prior to the financial cri- sis, during the financial crisis, and the period after the financial crisis of 2013 in Indonesia Capital Market. The results and conclusions that there is no difference in the behavior of disposition effect on the condition before the financial crisis, at the time of the financial crisis, and the period after the financial crisis of 2013 in Indonesia capital market.

The results of this study that show that there is no disposition effect behavior provide implications on the study of behavioral disposition effect in the financial crisis, especially in Indonesia in 2013 with the EMPI approach and the implication to the investor is could get higher return overall with holds more longer the share that give profit and quickly sell the share that prices drop, with holding the stock that prices tend to go up, so the investor could get the profit from the stock momentum. This indicates that investors have had enough experience in investing and had enough information so that in decision making has been able to make the right decision in addition to the availability of information.

\section{References}

Agarwal, S., Chiu, I-M., Liu, C., \& Rhee, S. G. (2010). The brokerage firm effect in herding: Evidence from Indonesia. The Journal of Financial Research, XXXIII(4), 317-337.

Armansyah, R. F. \& Effendi, M. B. (2017). Modeling the financial crisis in Indonesia. Journal of Economics, Business, and Accountancy Ventura, 20 (2), $125-136$.

Bodie, Z., Kane, A., \& Marcus, A. J. (2008). Investments. Sixth Edition. New York, USA: McGrawHill Companies Inc.

Bonser-Neal, C. S. L., Jones, D., Linnan, \& Neal, R. (2002). Herding and feedback trading by foreign investors: The case of Indonesia during the Asian financial crisis. Working paper.

Booth, G., Kallunki, J., Sahlstro, P., \& Tyynela, J. (2011). Foreign vs domestic investors and the post announcement drift. International Journal of Managerial Finance, 7(3), 220-237.

Bowe, M., \& Domuta, D. (2004). Investor herding during financial crisis: A clinical study of the Jakarta Stock Exchange. Pacific-Basin Finance Journal, 12(4), 387-418.

Dhar, R., \& Zu, N. (2006). Up close and personal: Investor sophistication and the disposition effect. Management Science, 52(5), 726-740.

Eichengreen, B., Rose, A. K., \& Wyplosz, C. (1994). Speculative attacks on pegged exchange rates: An emperical investigation, NBER Working Paper, No. 4898. 
Goetzmann, W. N., \& Massa, M. (2008). Disposition matters: Volume, volatility, and price impact of behavioral bias. Discussion Paper No. 4814.

Gomes, F. J. (2005). Portfolio choice and trading volume with loss-averse investors. The Journal of Business, 78(2), 675-706.

Grinblatt, M., \& Han, B. (2005). Prospect theory, mental accounting and momentum. Journal of Financial Economics, 78, 311-339.

Heun, M., \& Schlink, T. (2004). Early warning systems of financial crises - Implementation of a currency crisis model for Uganda. Working Paper. Frankfurt School of Finance \& Management No. 59.

Indrayono, Y. (2011). Disposition effect terhadap hubungan antara nilai fundamental dan harga saham pada periode krisis finansial. Jurnal Keuangan dan Perbankan, 15(3), 315-326.

Kahneman, D., \& Tversky, A. (1979). Prospect theory: An analysis of decision under risk. Econometrica, 47(2), 263-291.
Kaminsky, G., Lizondo, S., \& Reinhart, C. (1998). Leading indicators of currency crises., International Monetary Fund Staff Papers, 45(1), 1-48.

Lintner, G. (1998). Behavioral finance: Why investors makes bad decisions. The Planner, 13(1), 7-8.

Odean, T. (1998). Are investors reluctant to realize their losses? Journal of Finance, 53(5), 17751798.

Riaz, L., Hunjra, A. I., \& Azam, R. I. (2012). Impact of psychological factors on investment decision making mediating by risk perception: A conceptual study. Middle-East Journal of Scientific Research, 12(6): 789-795.

Ricciardi V. \& Simon, H. K. (2000). What is behavioral finance? Business, Education, \& Technology Journal, 2(2), 1 -9.

Ritter, J. R. (2003). Behavioral finance. Pacific-Basin Finance Journal, 11(4), 429-437.

Shefrin, H. \& Statman, M. (1985). The disposition to sell winners too early and ride losers too long: Theory and evidence. Journal of Finance, 40(3), 777-790. 